\title{
Thinking beyond the State
}





\title{
Thinking beyond the State
}

\author{
Marc Abélès
}

\author{
Translated by \\ Phillip Rousseau and \\ Marie-Claude Haince
}

Cornell University Press

Ithaca and London 
Originally published as Penser au-delà de l'État

Copyright (๑) Editions Belin, 2014

English translation copyright $\odot 2017$ by Cornell University

All rights reserved. Except for brief quotations in a review, this book, or parts thereof, must not be reproduced in any form without permission in writing from the publisher. For information, address Cornell University Press, Sage House, 512 East State Street, Ithaca, New York 14850.

First published 2017 by Cornell University Press

Printed in the United States of America

Library of Congress Cataloging-in-Publication Data

Names: Abélès, Marc, author. | Rousseau, Phillip, 1975- translator. |

Haince, Marie-Claude, 1978- translator. | Translation of: Abélès, Marc.

Penser au-delà de l'État.

Title: Thinking beyond the state / Marc Abélès ; translation by Phillip

Rousseau and Marie-Claude Haince.

Other titles: Penser au-delà de l'État. English

Description: Ithaca, New York : Cornell University Press, 2017. | Includes bibliographical references and index. | Description based on print version record and CIP data provided by publisher; resource not viewed.

Identifiers: LCCN 2017007548 (print) | LCCN 2017021987 (ebook) |

ISBN 9781501712005 (epub/mobi) | ISBN 9781501709364 (pdf) |

ISBN 9781501709272 (cloth : alk. paper) |

ISBN 9781501709289 (pbk. : alk. paper)

Subjects: LCSH: Nation-state and globalization. | Globalization-Social

aspects. | International economic integration-Political aspects. |

International economic relations-Political aspects. |

Political science-Philosophy.

Classification: LCC JZ1316 (ebook) | LCC JZ1316 .A2313 2017 (print) |

DDC 327.101—dc23

LC record available at https://lccn.loc.gov/2017007548

Cornell University Press strives to use environmentally responsible suppliers and materials to the fullest extent possible in the publishing of its books.

Such materials include vegetable-based, low-VOC inks and acid-free papers that are recycled, totally chlorine-free, or partly composed of nonwood fibers. For further information, visit our website at cornellpress.cornell.edu. 